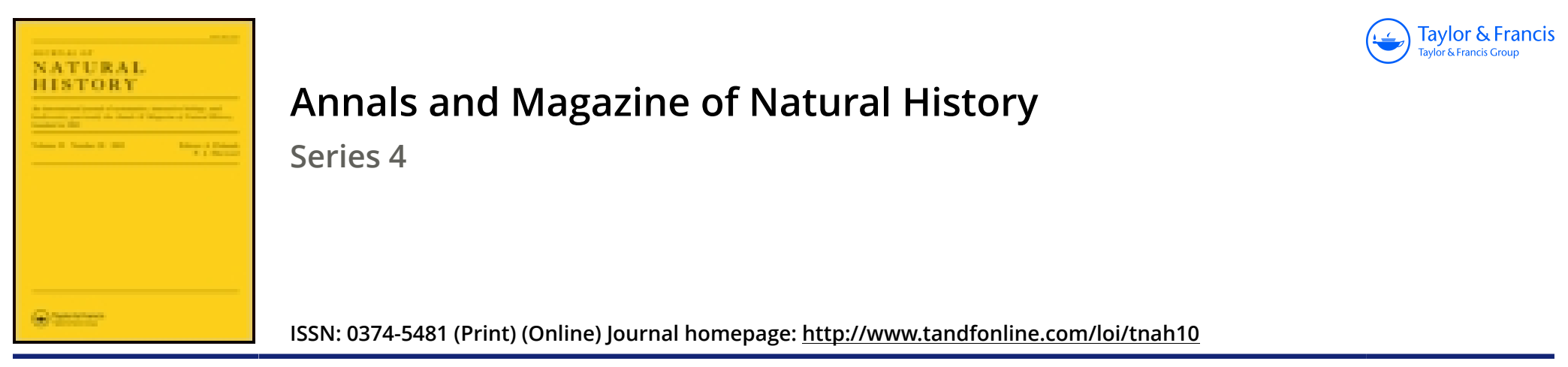

\title{
XXI.-On the invertebrate marine fauna and fishes of St. Andrews
}

\author{
W.C. M'Intosh M.D.
}

To cite this article: W.C. M'Intosh M.D. (1874) XXI.-On the invertebrate marine fauna and fishes of St. Andrews, Annals and Magazine of Natural History, 13:74, 140-145, DOI: 10.1080/00222937408680827

To link to this article: http://dx.doi.org/10.1080/00222937408680827

$$
\text { 册 Published online: } 13 \text { Oct } 2009 .
$$

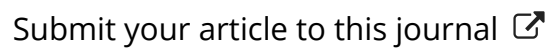

Џ Article views: 2

Q View related articles $\sqsubset$

4 Citing articles: 1 View citing articles 진 
XXI.-On the Invertebrate Marine Fauna and Fishes of St. Andrews. By W. C. M'InTosh, M.D. \&c.

\section{INTRODUCTION.}

The beach at St. Andrews combines smooth sandy flats with tide-worn ridges of rocks which freely communicate with the German Ocean ; and the proximity to rich coralline ground renders the products of its storms peculiarly varied. An unbroken surface of pure sand extends from the estuary of the Tay past that of the Eden to the north-western border of the city. From this point the rocks run eastward in parallel rows-narrow sandy flats intervening between some of the ridges, which, with one exception, are all covered at high water. Lines of rocks having a similar arrangement fringe the Castle and Pier to the east sands; then a coarse sandy and gravelly beach extends in a southerly direction about half a mile, after which the jagged rocky border passes round the eastern coast to the Frith of Forth.

The greater part of the sandy bay has a depth of less than 10 fathoms; for at this point the 20-fathom line bends outwards to the Bell rock. The whole region is thus comparatively shallow, and in contrast with that to the north of Arbroath Road, or with the Frith of Forth and the neighbouring coast on the south.

If the fine stretch of sand from the river Eden to the city (usually termed the West Sands in contradistinction to the East Sands) which extends to the harbour southward is only enlivened in summer by thousands of bleached heart urchins, broken shells, skeletons of plaice, frogfish, and haddock, or in autumn by the jellies of the medusa, the storms of winter and spring wholly alter the aspect. Immense banks of seaweeds mingled with black fragments of wood, coal, and muddy matter cover the beach, which in many parts becomes brilliantly phosphorescent at night from the zoophytes and annelids on the blades of the tangles. Amidst this débris are vast numbers of sponges, zoophytes, shells, starfishes, annelids, crabs, and fishes which have been swept from their various habitats. All storms are not equally prolific; they also vary in regard to the abundance of the several groups-a feature probably due to the direction of the wind and the invasion of particular sites. The waste of marine life in such storms does not attract much notice; yet it is extraordinary and so constant that it may be regarded to some extent as a check upon its uninterrupted development. It is, however, to be remembered that even the autumnal ripple in the Outer Hebrides brings 
countless swarms of Salpoe, Velellee, Medusa, and other forms to die on the beach.

The tidal rocks, again, which are mostly covered by seaweeds, present a varied and prolific site for many species. The rock-pools are both frequent and picturesque; and they possess many undisturbed stones, often of large size, the under surfaces of which are most favourable for the growth and shelter of numerous forms-though of course they cannot be compared in this respect with the littoral stones at Herm, which have a profusion of rare crabs, annelids, ormers and other mollusks, polyzoa, hydroids, and the yellow, red, purple, green, and white sponges. The soft sandstone and shale afford an ample field for the perforations of Pholas crispata, Saxicava rugosa, and Leucodore ciliata. The fissures and chinks of the rocks, moreover, as on almost every part of the British shores, give shelter to a large number, especially the annelids, which find in the muddy or sandy crevices a safe retreat for their soft bodies, slender tubes, or muddy tunnels, and opportunities for capturing sufficient food at the free margin of the rock or from the ingoing currents. It is chiefly in such localities that Sipunculus Johnstoni and swarms of Leucodore and Nicomache occur, while Nereis cultrifera, Eulalia, Syllis, and the nemerteans are also common. Occasionally an Idotea is met with; but the general absence of the isopods in these crevices distinguishes them from those in the gneiss of the south and west, as in the Channel Islands and the Outer Hebridesand especially from the former by the absence of Pilumnus hirtellus, Arca, the Sabellido, the Eunicidae and their allies. To these fissures certain boring annelids and Saxicava chiefly retreat when the rocks do not afford a suitable medium for their perforations-though at St. Andrews there is free scope in this respect, from the sandstones and shales so soft as to be pitted deeply by the common limpet to those nearly as dense as granite.

The sea-margin at St. Andrews, like other parts of the east coast of Scotland, presents decided differences when contrasted with the northern, southern, and western shores, though many forms are common to all. Thus the laminarian zone at St. Andrews is much less luxuriant than that of the Zetlandic waters with the fine forests of gigantic tangles, amidst which there is a galaxy of animal life. The vegetation of its littoral zone is surpassed by the rich Fuci of the tidal rocks and the trailing masses of Chorda filum on the surface of the sea immediately beyond low-water mark in the Outer Hebrides. Its marine forms are placed under very different circumstances from those in the quiet voes of West Shetland, Ann. \& Mag. N. Hist. Ser. 4. Vol. xiii. 
as at Cliff Sound and between the Burras, where the still seawater is bridged by a single arch of a few feet. To represent the Zostera-fields of the west and south there are but a few Conferve, Ulva, and Porphyroe attached to stones on the flat surfaces of the beach. The calcareous rocks of the south, and the multitudes of worm-eaten boulders scattered on many parts of the shore, as in the Isle of Wight, form likewise a boldly marked contrast.

Within reach of the modern tide, also, it is interesting to find the remains of oceanic animals long since extinct-to see Actinia mesembryanthemum attached to a mass of encrinite stalks, Litorina rudis in groups on Lingula-shale, and the white coils of Spirorbis incrusting a nodule containing a fossil fish. Yet these features do not appear much out of place near a city whose pier is to a considerable extent constructed of the fine old stones and ancient oak which once formed part of the splendid pile of its cathedral.

On the whole the zoological features of St. Andrews are northern.

\section{Subkingdom PROTOZOA. \\ Class RHIZOPODA.}

\section{Order Spongiadæ.}

The Sponges of St. Andrews are, perhaps, the least-investigated group, partly because a collection carefully made many years ago has been lost. In looking over those obtained since, Dr. Bowerbank has most kindly given his experienced aid in doubtful cases; and the description of the new species is solely his. The littoral forms are scattered in considerable profusion between tide-marks under ledges and stones, sometimes near high-water mark. Indeed, in the higher pools and tide-runs in the latter region they are often peculiarly luxuriant. The brightly coloured Halisarca, so abundant on the under surfaces of stones in the Hebrides, and the rarer botryoidal Tethea are unknown at St. Andrews, as are likewise the cup and turnip sponges of the Zetlandic seas. The greater luxuriance of the ubiquitous Halichondria panicea on the tems of the Laminariæ further characterizes the coast of the extreme west; and the decay of the seaweed often leaves tubes of sponge from a foot to eighteen inches in length. In like manner the greatly increased size of $G$ rantia ciliata, the vast abundance of Hymeniacidon celata, its beautiful arborescent patterns in the tide-worn shells, and its perforations in the limestone rocks are diagnostic of the warmer waters of the southern coast. 
The classification of Dr. Bowerbank in his valuable work published by the Ray Society has been that followed in the list.

\section{Suborder I. Calcarea.}

Grantia compressa, Fabr.; Bowerb. Brit. Spong. ii. p. 17.

Abundant on Cynthia grossularia under shelving rocks between tide-marks, and attached to the roots of Fuci and other seaweeds. It occasionally assumes an abnormal form, and has a broad attached surface under stones. Longest, 3 inches.

Grantia ciliata, Fabr.; Bowerb. vol. ii. p. 19.

Not unfrequent on laminarian roots cast on the west sands after storms, and growing near low-water mark at the East Rocks. The species somewhat resembles a grain of oat removed from its husk.

Leucosolenia botryoides, Ellis \& Sol.; Bowerb. vol. ii. p. 28.

Abundant on the under surfaces of stones in tidal pools, especially if large and little-disturbed. It frequently accompanies Grantia compressa.

Leuconia nivea, Grant; Bowerb. vol. ii. p. 36.

Found abundantly in the deeper tidal pools, under large stones which have been long untouched. It covers spaces several inches square; and its margin is generally rounded and "finished" like the border of a lichen. Most of the specimens have their surfaces elevated into firm rugæ, resembling: miniature mountain-ranges, some of the crests rising into flattened lobes $\frac{3}{4}$ inch in height. There are at least two varieties of this sponge-the first of which, besides the equiangular triradiate spicula of the skeleton, the minute acerate ones of the interstitial and dermal membranes, and the unicurvo-cruciform, has many spined acuate spicula of considerable dimensions and others of the same size approaching the fusiformi-spinulate character. In the other variety the latter kinds are so little developed, if present, as not to be distinguished from the ordinary minute acerate forms. In both, almost all the latter are distinctly spined.

\section{Suborder II. Sruicea.}

Hymeniacidon ficus, Fsper; Bowerb. vol. ii. p. 206.

Occasionally from deep water, attached to dead shells. Clavate specimens frequently grow from the smaller end of Dentalium entalis. This species seems to frequent muddy ground. 
Hymeniacidon celata, Grant; Bowerb. vol. ii. p. 212.

Abundant in shells from deep water, between the layers of which it tunnels its devious tracks. This is one of the main agents in causing the disintegration of dead shells.

Halichondria panicea, Pallas ; Bowerb. vol. ii. p. 229.

Scarcely a stone can be lifted near low-water mark, amongst the rocks, but has a patch of this common sponge. Under the cavernous ledges overhanging rock-pools it spreads its structure over the dark red Cynthia, matting together seaweeds and corallines, and hanging in pendulous nodules on interwoven stalks of Corallina officinalis and Fuci. Near the Maiden Rock splendid specimens are found incrusting a square foot or two of rock in some of the quiet pools. It also abounds on the backs of crabs, such as Hyas araneus and Inachus dorynchus, covering the former so completely that it can scarcely be recognized except by its legs; and besides the prominent oscula of the sponge, on this complex back are gaps for Balani, shells, and seaweeds. On the carapace of the latter species it forms a thinner coating, but is likewise grouped in little nodules on the legs. A mass as large as a good-sized apple surrounds the stem of Chalina oculata; and it is a common envelopment of various stones, mollusks, seaweeds, and tangle-roots. The usual colours of the sponge are yellow, brown, purple, green, and grey. In the interstices of the masses thrown on shore at the West Sands are to be found multitudes of marine animals, besides incorporated shells; and the fine patches at the East Rocks are favourite feeding-grounds of Doris tuberculata. The forms of the spicula of this species are variable, some being much curved like a stretched bow, a few more or less inæquiacerate vermiculoid, besides, of course, the ordinary diagnostic spicula. The odour emitted on tearing it from the rock is characteristic, but causes no sneezing,

\section{Halichondria, n. s.*}

The following is Dr. Bowerbank's description:-_ "Sponge coating, thin. Surface smooth and even. Oscula more or less elevated, dispersed, margins thin. Pores inconspicuous. Dermal membrane aspiculous. Skeleton very irregular, rete mostly unispiculous, occasionally bi- or trispiculous; spicula acerate, short and stout. Interstitial membranes aspiculous.

"Colour in the dried state light nut-brown. Examined in the living and dried states.

"The nearest alliance with the known species of the first

* Dr. Bowerbank has courteously named this species $H$. M'Intoshii, Bowerb. 
section of our British Halichondrioe is with H. regularis. The spicula of the two species are as nearly alike in size and proportions as possible; but this is their only approximation to each other. In their other characters they differ to a considerable extent. The colour of $H$. regularis in the dried state is milk-white; that of $H . M^{\prime}$ Intoshii is nut-brown. Another important difference is, that while the skeleton of $H$. regularis is remarkable for its symmetry, that of $H$. $M^{\prime}$ Intoshii is irregular to a very considerable degree."

This form is not uncommon on the under surface of stones in tide-runs and somewhat muddy pools not far from highwater mark at the East Rocks. Its greyish brown colour, smooth surface, and prominent, well-defined oscula distinguish it at first sight from its allies.

Halichondria incrustans, Esper; Bowerb. vol. ii. p. 249.

Occasionally found under stones near low-water mark, especially at the East Rocks. It forms a thickish crust; and the spicula very much resemble one of the knobbed walkingsticks which taper from above downwards.

\section{Suborder III. Keratosa.}

Chalina oculata, Pallas; Bowerb. vol. ii. p. 361.

Thrown in great profusion on the West Sands after storms; and small specimens are also found under the ledges of rocks near low-water mark. The shape of the specimens varies much : some are flattened and much divided into branches of various sizes, either narrow or broad; others have their branches much matted together so as to form a connected and somewhat coarse "gorgonian" appearance, more or less separated at the tip. In some the branches arise mostly from one side of an unbroken prolongation of the sponge-tissue. One grows on a valve of Mytilus modiolus, and has a mass of Halichondria panicea round a branch at its base. Another envelops the stem and branches of Delesseria sanguinea, the leaves of which appear here and there from the centre of the sponge. Many are attached to small rolled stones. Those from the beach are loaded with sand, spines of the common and purple heart urchins, bristles of the sea-mouse; and many starfishes seek refuge in their interstices.

Chalina limbata, Bowerb.; vol. ii. p. 373.

Not uncommon on the under surfaces of stones in tidal pools, either coating the surface of the stone or attached to the stems of Corallina officinalis.

[To be continued.] 